\title{
The New Red List of the molluscs of Latvia
}

\section{Mudīte Rudzīte ${ }^{1 *}$, Elmīra Boikova², Edgars Dreijers³ ${ }^{3}$ Iveta Jakubāne ${ }^{4}$, Elga Parele ${ }^{2}$, Digna Pilāte $^{5}$, Māris Rudzītis ${ }^{6}$}

\author{
${ }^{1}$ Museum of Zoology, University of Latvia, Kronvalda bulv. 4, Rīga LV-1586, Latvia \\ ${ }^{2}$ Institute of Biology, University of Latvia, Miera 3, Salaspils LV-2169, Latvia \\ ${ }^{3}$ Latvian Museum of Natural History, Krišjāna Barona 4, Rīga LV-1050, Latvia \\ ${ }^{4}$ Daugavpils University, Institute of Life Science and Tehnology, Parādes 1A, Daugavpils LV-5401, Latvia \\ ${ }^{5}$ Latvian State Forest Research Institute "Silava", Rīgas 111, Salaspils LV-2169, Latvia \\ ${ }^{6}$ Museum of Geology, University of Latvia, Alberta 10, Rìga LV-1010, Latvia \\ ${ }^{\star}$ Corresponding author, E-mail: mudite.rudzite@lu.lv
}

\begin{abstract}
A new list of protected molluscs in Latvia - the New Red List - has been prepared. It includes 39 species from 170 species found in Latvia. The category 0 has no species, there is 1 species in the first category, 6 species in the second category, 25 species in the third category, and 7 species in the fourth category. Evaluation criteria similar to these in the previously published Red Books have been used. Information on 64 species included in the IUCN LC category is also collected. There is no need for special protection measures for these species; however, the dynamics of their populations should be monitored.
\end{abstract}

Key words: Latvia, mollusc species, protection status.

\section{Introduction}

The first Red Data Book of Latvia was published 33 years ago (Aigare et al. 1985), and only one species - freshwater pearl mussel Margaritifera margaritifera - was included in it, in the 1st category. The second, expanded edition of the Red Data Book of Latvia (Spuris 1998) was published 20 years ago, and it contained 29 species of molluscs. The definitions of categories in both editions were quite similar, except only the 0 category (category of extinct species). In the preparation of the second edition more attention was paid to the IUCN Red List of Threatened Animals (IUCN 1996).

The first modern synopsis of molluscs of Latvia was published in 1942 (Schlesch 1942). It contained all published and research data in 1930-ies. In 1950-ies the information about mollusc species was summarized in the Identification Keys to Animals in Latvia (Sloka, Sloka 1957). The list of Latvian molluscs was published later, in 1997 (Rudzite et al. 1997). The latest data about molluscs in Latvia was published in the Guide to the Molluscs of Latvia (Rudzìte et al. 2010). Updated list of molluscs of Latvia has been prepared during last years (Rudzite et al. 2018). The information about mollusc fauna in the Baltic States was also summarized (Stalažs, Dreijers 2016).

The updated New Red List of the molluscs of Latvia assesses the status of each species and the current legislation of the Republic of Latvia adequacy to the internationally recognized documents.

\section{Red List categories}

The definitions of the following categories are based on the slightly amended definitions of the Red Book of Latvia (Spuris 1998).

0: extinct species, not encountered in nature for the recent 50 years, yet possibly have survived in separate places in nature, in captivity, or in cultures; they need a special government protection by law (Spuris 1998). Currently, from mollusc species found in Latvia, none corresponds to this category. In the Red Data Book of Latvia (Spuris 1998) the species Helicigona lapicida (Linnaeus, 1758) and Truncatellina cylindrica (A. Férussac, 1807) were included in the $0^{\text {th }}$ category because they have not been found in Latvia for 50 years, since 1930-ies up to 1990-ies. Later these species were found several times (Rudzite et al. 2010).

1: endangered species; unless some changes are made, will probably become extinct, their number has diminished to the critical limit; they need a special government care in protection by regulations and by specific or definite measures. There is one species in this category, Margaritifera margaritifera, included in the Apendix II of the Convention of the Conservation of European Wildlife and Natural Habitats, Bern, 1979 (Convention 1979).

2: vulnerable species decreasing in number, the areal of these species diminishes in the course of years either due to natural reasons or human activity, or both; they need control on further changes in their number, and a special government care and protection by regulations and 
measures. There are six species in this category.

3: rare species, no threat of extiction as yet, although encountered in such a small number or in so limited areas and specified sites that they may probably disappear; they need a special government care and protection by regulations and measures. There are 25 species in this category.
4: undetermined species, species insufficiently studied; probably endangered, yet due to the lack of information it is impossible to give an exact estimation of their present status; a deeper study is needed. There are seven species in this category.

The New Red List of molluscs of Latvia is presented in Table 1.

Table 1. The New Red List of molluscs of Latvia. Influencing factors: the main factors that influences the state of the species in Latvia. A, the fragmentation of natural habitats that restrict populations and does not allow the species to spread further; B, decrease and degradation of natural habitat areas as a result of the human activity or ecological succession; $\mathrm{C}$, decrease and degradation of natural habitats due to spreading of an expansive species; $\mathrm{D}$, water pollution due to human activities, $\mathrm{E}$, intentional use in the interests of humans. IUCN: categories used are from the IUCN Red List version 3.1. (IUCN 2017). EN, endangered; VU, vulnerable; NT, near threatened; LC, least concern; DD, data deficient; ver. 2.3, Version 2.3 (needs updating). EC Directive: The Habitats Directive (Directive 1992). II, species included in the Annex II (Animal and plants species of community interest whose conservation requires the designation of special areas of conservation); IV, species included in the Annex IV (Animal and plant species of community interest in need of strict protection); $\mathrm{V}$, species included in the Annex V (Animal and plant species of community interest whose taking in the wild and exploitation may be subject to management measures). Protected: 1, species included in Annex I (List of specially protected species of Regulations of Cabinet of Ministers of Republic of Latvia for list of specially protected species and of species of limited exploitation, Regulation No. 396, Annex I, II on 14 November 2000, amended as Regulation No. 627, Annex I, on 27 July 2004; 2, species included in Annex II (List of species of limited exploitation, the same Regulations). Microreserves: +, species included in the List of Species of the Regulations of the Cabinet of Ministers of Republic of Latvia No. 940 adopted on December 18, 2012 (Regulation on Microreserve Establishment and Management Procedure, Their Protection, as well as Identification of Microreserves and Their Bufferzones). ${ }^{1}$ We need a reservation about Arion rufus that the category concerns only the local red slug populations and does not concern the synanthropical ones that were brought to Latvia by humans. ${ }^{2}$ Parvicardium hauniense evaluated Vulnerable in HELCOM Red List of Baltic Sea species (HELCOM 2013). ${ }^{3}$ Alderia modesta was evaluated as Near Threatened in HELCOM Red List of Baltic Sea species (HELCOM 2013), it has recently been found in Latvian territorial waters by V. Jermakovs (personal report about Alderia modesta occurrence in Latvian territorial waters)

\begin{tabular}{|c|c|c|c|c|c|}
\hline Species & $\begin{array}{l}\text { Influencing } \\
\text { factors }\end{array}$ & IUCN & EC Directive & Protected & Microreserves \\
\hline \multicolumn{6}{|c|}{ Category 1} \\
\hline Margaritifera margaritifera (Linnaeus, 1758) & $\mathrm{A}, \mathrm{B}, \mathrm{C}, \mathrm{D}, \mathrm{E}$ & EN & II, V & 1 & + \\
\hline \multicolumn{6}{|c|}{ Category 2} \\
\hline Theodoxus fluviatilis (Linnaeus, 1758) & $A, B, C, D$ & $\mathrm{LC}$ & & 1 & \\
\hline Vertigo angustior Jeffreys, 1830 & $\mathrm{~B}$ & NT & II & 1 & \\
\hline Vertigo genesii (Gredler, 1856) & B & $\mathrm{LC}$ & II & 1 & + \\
\hline Vertigo geyeri Lindholm, 1925 & B & $\mathrm{LC}$ & II & 1 & + \\
\hline Vertigo moulinsiana (Dupuy, 1849) & $\mathrm{A}, \mathrm{B}$ & VU & II & & + \\
\hline Unio crassus Philipsson, 1788 & $\mathrm{~A}, \mathrm{~B}, \mathrm{C}, \mathrm{D}, \mathrm{E}$ & $\mathrm{EN}$ & II, IV & 1 & + \\
\hline \multicolumn{6}{|c|}{ Category 3} \\
\hline Platyla polita (W. Hartmann, 1840) & $A, B$ & $\mathrm{LC}$ & & 1 & \\
\hline Myxas glutinosa (O. F. Müller, 1774) & $A, D$ & DD ver 2.3 & & & \\
\hline Gyraulus crista (Linnaeus, 1758) & $\mathrm{A}, \mathrm{D}$ & $\mathrm{LC}$ & & & \\
\hline Cochlicopa nitens (M. von Gallenstein, 1848) & $A, B$ & LR/LC ver 2.3 & & 1 & \\
\hline Spermodea lamellata (Jeffreys, 1830) & $A, B$ & NT & & 1 & \\
\hline Truncatellina cylindrica (A. Férussac, 1807) & $A, B$ & & & 1 & \\
\hline Vertigo lilljeborgi (Westerlund, 1871) & $A, B$ & NT & & & \\
\hline Ena montana (Draparnaud, 1801) & $A, B$ & $\mathrm{LC}$ & & 1 & + \\
\hline Merdigera obscura Held, 1838 & $A, B$ & LC & & 1 & \\
\hline Bulgarica cana (Held, 1836) & $A, B$ & LC & & 1 & \\
\hline Clausilia bidentata (Ström, 1765) & $\mathrm{A}, \mathrm{B}$ & $\mathrm{LC}$ & & 1 & \\
\hline Clausilia cruciata (S. Studer, 1820) & $A, B$ & $\mathrm{LC}$ & & 1 & + \\
\hline Clausilia dubia Draparnaud, 1805 & $A, B$ & $\mathrm{LC}$ & & 1 & \\
\hline Clausilia pumila C. Pfeiffer, 1828 & $A, B$ & $\mathrm{LC}$ & & 1 & \\
\hline Cochlodina orthostoma (Menke, 1828) & $A, B$ & LC & & 1 & \\
\hline
\end{tabular}

continued 
Table 1. continued

\begin{tabular}{|c|c|c|c|c|c|}
\hline Species & $\begin{array}{c}\text { Influencing } \\
\text { factors }\end{array}$ & IUCN & EC Directive & Protected & Microreserves \\
\hline Macrogastra borealis (O. Boettger, 1878) & $\mathrm{A}, \mathrm{B}$ & LC & & 1 & + \\
\hline Ruthenica filograna (Rossmässler, 1836) & $A, B$ & LC & & 1 & \\
\hline Oxychilus alliarius (J.S. Miller, 1822) & $\mathrm{A}, \mathrm{B}$ & LC & & & \\
\hline Arion rufus (Linnaeus, $1758^{1}$ & $\mathrm{~A}, \mathrm{~B}, \mathrm{C}$ & LC & & & \\
\hline Isognomostoma isognomostomos (Schröter, 1784) & $A, B$ & LC & & 1 & + \\
\hline Helicigona lapicida (Linnaeus, 1758) & $\mathrm{A}, \mathrm{B}$ & LC & & 1 & + \\
\hline Pseudanodonta complanata (Rossmässler, 1835) & $\mathrm{A}, \mathrm{D}$ & VU & & & \\
\hline Musculium lacustre (O. F. Müller, 1774) & A, D & LC & & & \\
\hline Sphaerium rivicola (Lamarck, 1818) & A, D & $\mathrm{VU}$ & & & \\
\hline Parvicardium hauniense (Petersen \& Russell, 1971) ${ }^{2}$ & $\mathrm{~A}, \mathrm{D}$ & VU & & & \\
\hline \multicolumn{6}{|c|}{ Category 4} \\
\hline Alderia modesta (Lovén, 1844$)^{3}$ & A & & & & \\
\hline Valvata cristata O. F. Müller, 1774 & A & & & & \\
\hline Anisus vorticulus (Troschel, 1834) & A & $\mathrm{DD}$ & & & \\
\hline Vertigo ronnebyensis (Westerlund, 1871) & $\mathrm{A}, \mathrm{B}$ & LC & & & \\
\hline Cecilioides acicula (O.F. Müller, 1774) & A & & & & \\
\hline Vitrea contracta (Westerlund, 1871) & A & & & & \\
\hline Sphaerium solidum (Normand, 1844) & A, D & NT & & & \\
\hline
\end{tabular}

\section{The IUCN Red List species}

A special attention should be paid to 64 species, both native and not native, occurring in Latvia that needs internationally admitted care, i.e. the species are included in the IUCN Red List as an LC category species (Table 2). For the moment these species do not require state protection in the form of legislative acts.

Table 2. Mollusc species that are included in the IUCN REd List as LC category species. Distribution and occurrence in Latvia: vf, very frequent; f, frequent; rf, relatively frequent; nf, not frequent; r, rare; vr, very rare; d, distribution to be specified; ?, status to be specified; il (number indicated), isolated locality (Rudzite et al. 2018). Annotations: indicated belonging to the local fauna of Latvia as native or not native. Eleven of these species have been found in archaeological excavations that prove their belonging to the local fauna. However, the material obtained from the excavation shows only a part of the species of postglacial time (Rudzìte et al. 2012; Berzins et al. 2014; Bērziňš et al. 2016; for some species also unpublished data and material in the Museum of Zoology of University of Latvia)

\begin{tabular}{|c|c|c|}
\hline Species & Distribution and occurrence & Annotations \\
\hline Viviparus contectus (Millet, 1813) & $\mathrm{f}$ & native, in archeological samples \\
\hline Viviparus viviparus (Linnaeus, 1758) & $\mathrm{f}$ & native \\
\hline Bithynia leachii (Sheppard, 1823) & $\mathrm{rf}$ & native, in archeological samples \\
\hline Bithynia tentaculata (Linnaeus, 1758) & $\mathrm{vf}$ & native, in archeological samples \\
\hline Ecrobia ventrosa (Montagu, 1803) & $\mathrm{nf}$ & native, in archeological samples \\
\hline Potamopyrgus antipodarum (J. E. Gray, 1843) & $\mathrm{nf}$ & not native \\
\hline Borysthenia naticina (Menke, 1845) & $\mathrm{nf}$ & not native \\
\hline Valvata macrostoma Mörch, 1864 & $\mathrm{nf}$ & native, in archeological samples \\
\hline Valvata piscinalis (O. F. Müller, 1774) & vf & native, in archeological samples \\
\hline Acroloxus lacustris (Linnaeus, 1758) & $\mathrm{f}$ & native, in archeological samples \\
\hline Galba truncatula (O. F. Müller, 1774) & $\mathrm{f}$ & native \\
\hline Lymnaea stagnalis (Linnaeus, 1758) & vf & native, in archeological samples \\
\hline Radix auricularia (Linnaeus, 1758) & $\mathrm{f}$ & native \\
\hline Radix balthica (Linnaeus, 1758) & $\mathrm{d}$ & ? \\
\hline Stagnicola corvus (Gmelin, 1791) & d & ? \\
\hline Stagnicola fuscus (C. Pfeiffer, 1821) & $\mathrm{d}$ & ? \\
\hline Stagnicola palustris (O. F. Müller, 1774) & $\mathrm{d}$ & ? \\
\hline
\end{tabular}

continued 
Table 2. continued

\begin{tabular}{|c|c|c|}
\hline Species & Distribution and occurrence & Annotations \\
\hline Stagnicola turricula (Held, 1836) & $\mathrm{d}$ & ? \\
\hline Physa fontinalis (Linnaeus, 1758) & $\mathrm{f}$ & native \\
\hline Anisus leucostoma (Millet, 1813) & $\mathrm{r}$ & native \\
\hline Bathyomphalus contortus (Linnaeus, 1758) & $\mathrm{f}$ & native \\
\hline Gyraulus albus (O. F. Müller, 1774) & $\mathrm{rf}$ & native \\
\hline Gyraulus laevis (Alder, 1838) & $\mathrm{r}$ & native \\
\hline Gyraulus rossmaessleri (Auerswald, 1852) & $\mathrm{r}$ & native \\
\hline Hippeutis complanatus (Linnaeus, 1758) & $\mathrm{rf}$ & native \\
\hline Planorbarius corneus (Linnaeus, 1758) & vf & native, in archeological samples \\
\hline Planorbis planorbis (Linnaeus, 1758) & vf & native \\
\hline Pupilla muscorum (Linnaeus, 1758) & $\mathrm{nf}$ & native \\
\hline Columella edentula (Draparnaud, 1805) & vf & native \\
\hline Balea biplicata (Montagu, 1803) & $?$ & $?$ \\
\hline Laciniaria plicata (Draparnaud, 1801) & $\mathrm{rf}$ & native \\
\hline Macrogastra plicatula (Draparnaud, 1801) & $\mathrm{rf}$ & native \\
\hline Macrogastra ventricosa (Draparnaud, 1801) & $\mathrm{f}$ & native \\
\hline Vitrea crystallina (O. F. Müller, 1774) & $\mathrm{rf}$ & native \\
\hline Oxychilus cellarius (O. F. Müller, 1774) & il 3 & not native \\
\hline Oxychilus draparnaudi (H. Beck, 1837) & il 2 & not native \\
\hline Limacus flavus (Linnaeus, 1758) & il 1 & not native \\
\hline Malacolimax tenellus (O. F. Müller, 1774) & $\mathrm{rf}$ & native \\
\hline Deroceras sturanyi (Simroth, 1894) & $\mathrm{nf}$ & native \\
\hline Arion circumscriptus Johnston, 1828 & $\mathrm{f}$ & native \\
\hline Arion distinctus J. Mabille, 1868 & $?$ & $?$ \\
\hline Arion fasciatus (Nilsson, 1823) & $\mathrm{f}$ & native \\
\hline Arion fuscus (Draparnaud, 1805) & $\mathrm{f}$ & native \\
\hline Arion hortensis Ferussac, 1819 & $?$ & ? \\
\hline Fruticicola fruticum (O. F. Müller, 1774) & vf & native \\
\hline Euomphalia strigella (Draparnaud, 1801) & $\mathrm{nf}$ & native \\
\hline Monachoides incarnatus (O. F. Müller, 1774) & il 3 & native \\
\hline Perforatella bidentata (Gmelin, 1791) & $\mathrm{f}$ & native \\
\hline Pseudotrichia rubiginosa (Rossmässler, 1838) & $\mathrm{rf}$ & native \\
\hline Arianta arbustorum (Linnaeus, 1758) & vf & native and expansive \\
\hline Cepaea hortensis (O. F. Müller, 1774) & $\mathrm{rf}$ & native \\
\hline Cepaea nemoralis (Linnaeus, 1758) & $\mathrm{r}$ & not native, but stable populations \\
\hline Caucasotachea vindobonensis (Ferussac, 1821) & il 1 & not native \\
\hline Helix pomatia Linnaeus, 1758 & $\mathrm{rf}$ & not native, but stable populations \\
\hline Anodonta anatina (Linnaeus, 1758) & $\mathrm{f}$ & native \\
\hline Anodonta cygnea (Linnaeus, 1758) & $\mathrm{nf}$ & native \\
\hline Unio pictorum (Linnaeus, 1758) & $\mathrm{rf}$ & native, in archeological samples \\
\hline Unio tumidus Philipsson, 1788 & $\mathrm{f}$ & native, in archeological samples \\
\hline Pisidium casertanum (Poli, 1791) & $\mathrm{r}$ & native \\
\hline Pisidium henslowanum (Sheppard, 1823) & $\mathrm{rf}$ & native \\
\hline Pisidium obtusale (Lamarck, 1818) & $\mathrm{d}$ & native \\
\hline Pisidium supinum A. Schmidt, 1851 & $\mathrm{r}$ & native \\
\hline Sphaerium ovale (A. Férussac, 1807) & $\mathrm{d}$ & native \\
\hline Dreissena polymorpha (Pallas, 1771) & vf & not native \\
\hline
\end{tabular}

\section{Acknowledgements}

We are grateful to Vadims Jermakovs for the information about the marine benthic species on the Latvian coast.

\section{References}

Aigare V., Andrušaitis G., Lipsbergs J., Lodziņa I., Tabaka L. 1985. Red Data Book of the Latvian SSR. Rare and endangered 
species of animals and plants. Zinātne, Rīga. /in Latvian/

Berzins V., Brinker U., Klein Chr., Lübke H., Meadows J., Rudzite M., Schmölcke U., Stümpel H., Zagorska I. 2014. New research on Rinnukalns, a Neolithic freshwater shell midden in northern Latvia. Antiquity 88: 715-732.

Bērziņš V., Lübke H., Berga L., Ceriņa A., Kalniņa L., Meadows J., Muižniece S., Paegle S., Rudzìte M., Zagorska I. 2016. Recurrent Mesolithic-Neolithic occupation at Sise (western Latvia) and shoreline displacement in the Baltic Sea Basin. Holocene 26: 1-7.

Rudzīte M., Zagorska I, Lübke H., Bērzin̦š V. 2012. Molluscs from a new archaeological exavation at Riṇnukalns, Latvia. Schriften zur Malakozoologie 27: 49-56.

Convention. 1979. Convention of the Conservation of European Wildlife and Natural Habitats, Bern. Apendix II, Apendix III.

Directive. 1992. EC Directive 92/43/EEC on the Conservation of natural habitats and of wild fauna and flora.

IUCN. 1996. Red List of Treatened Animals. Gland, Switzerland.

IUCN. 2017. The IUCN Red List of Threatened Species. Version 2017-3. Downloaded on 16 March 2018. http://www. iucnredlist.org

HELCOM. 2013. Red List of Baltic Sea species in danger of becoming extinct. Baltic Sea Environment Proceedings No.
140. Finland.

Rudzīte M., Pilāte D., Parele E. 1997. Molluskenfauna Lettlands: Liste der in Lettland Molluskenarten (Gastropoda, Bivalvia). Mitteilungen der Deutschen Malakozoologischen Gesellschaft 59: $1-10$.

Rudzìte M., Dreijers E., Ozoliṇa-Moll L., Parele E., Pilāte D., Rudzītis M., Stalažs A. 2010. A Guide to the Molluscs of Latvia. LU Akadēmiskais apgāds, Rīga.

Rudzīte M., Boikova E., Dreijers E., Jakubāne I., Jermakos V., Parele E., Pilāte D., Rudzītis M. 2018 Distribution and protection the Molluscs of Latvia. Schriften zur Malakozoologie /in print/

Schlesch H. 1942. Die Land- und Süsswassermollusken Lettlands mit Berücksichtigung der in den Nachbargebieten vorkommenden Arten. Korrespondenzblatt des NaturforscherVereins zu Riga 64: 245-360.

Sloka N., Sloka J. 1957. Mollusca - Molluscs. Guide to Animals of Latvian SSR. Vol. 1, pp. 732-775. /in Latvian/

Spuris Z. (ed) 1998. Red Data Book of Latvia. Rare and endangered species of animals and plants. Volume 4. Invertebrates. Institute of Biology, Riga. /in Latvian/

Stalažs A., Dreijers E. 2016. Annotated checklist of the molluscs of the Baltic countries. Raksti par Dabu 2: 9-20. 